\title{
Influence of Ancient Mesopotamian Aesthetics of Gardens/Parks and Water Installations on the Development of Landscape Architecture
}

\author{
By Antanas Stančius ${ }^{*} \&$ Petras Grecevičius ${ }^{ \pm}$
}

\begin{abstract}
Based on the information from fundamental historical sources, the oldest origins of civilization can be found in the river valleys of the Tigris and the Euphrates. Throughout Mesopotamia important routes of trade and migration of peoples followed, which influenced the emergence and development of one of the world's first urban-type civilizations. It was here that the Sumerian civilization evolved, leading to a major cultural and technological breakthrough. Their widely used irrigation canals influenced not only the landscape, but also the entire ecological, economic and political systems of the time, water being a particularly important factor in this civilization. The oldest known gardens have also expanded here, and the Hanging Gardens of Babylon still fuel people's imagination. Due to its unique geographical location, the region has had a profound impact on the surrounding nations, and it is no accident that the Assyrian Imperial Parks of Northern Mesopotamia exerted a great influence on the civilizations that followed. Undoubtedly, ancient Mesopotamia occupies a fundamental place in the development of garden art. With the growing use of roof gardens and the use of plants in modern architectural constructions as an extremely important tool for composition, it is worth exploring more closely the origins of this landscape-relevant process.
\end{abstract}

\section{Introduction}

The knowledge gained from fundamental historical sources supports the statement that the origins of the oldest civilization are found in the valleys of the Tigris and Euphrates rivers. The territory of Mesopotamia is bordered on the north and the east by mountain ranges, on the south by the waters of the Persian Gulf, and on the west by desert areas. Unsurprisingly, due to the favorable natural conditions for agriculture, nomadic societies began to develop in these areas. The most fertile region consists of the areas between the two major rivers, where fertility was increased by the constantly renewed alluvial soil from water flows. However, there was a constant risk of river floods and droughts. In total, floods occurred as many as eight times a year, so it is not surprising that the region developed a complex system of irrigation, dikes, dams and canals. Artificial irrigation systems adapted in the southern part of Mesopotamia date back to the VI-V millennium BCE, which is a millennium earlier than in Egypt. Unlike other major river valley civilizations, the geography of this region does not have favorable natural barriers to protect against nomadic influxes, and that determines

${ }^{*}$ Lecturer, Vilnius Gediminas Technical University, Lithuania.

${ }^{ \pm}$Professor \& Project Manager, Center for Architecture, Urbanism and Design "Baltic Landscapes", Klaipeda University, Lithuania. 
the special dynamics of this region, which has left a strong mark on the culture of many later civilizations. ${ }^{1}$ However, despite the constant political changes in this region, the multicultural nature, the constant state of struggle, the stability of the visual and architectural unity of the Mesopotamian civilizational space is astonishing. Here, art not only empowered and reflected political power, but also developed a visual narrative in search of opportunities to convey narratives through art. $^{2}$ On the assumptions of other researchers, archaeological research, and aerial photographs, R. Pournelle arrived at the conclusion that the first water canals were used for navigation, transport, and trade, so there was no need for a long period of organized, mass slavery social development, as in Egypt, to lead to the establishment of an expanded hydraulic civilization. In her view, with the drying up of the climate and the onset of large-scale urbanization, this navigational experience was easily adapted to the subsequent engineering water system developed by perpendicular canals, dikes, dams, dams, reservoirs and irrigation furrows connecting Sumer crops, cities and the river form. ${ }^{3}$ Early urbanization, writing, cultural and technological developments led to the relatively early emergence of political systems in the region, and the formation of the first known historical empires. The political and social system of the ancient Sumerian citystates was based on the belief in the divine origin of the rulers, supported by the social stratum of the priests. S. N. Kramer's ${ }^{4}$ research also reveals the origins of democratic governance, which later spread widely in the Greek world. However, since the emergence of the first settlements, independent city-states have been fighting amongst themselves for political influence in the region, so the region had the characteristic nature of political fragmentation. Finally, the successful growth of food resources in Sumerian cities and the growing wealth due to trade ties did not go unnoticed by the surrounding nations, leading to the penetration of different communities of Semitic origin towards southern Mesopotamia. About 2334 BCE, the region was relatively easy to conquer by Sargon of Akkad who established the first Middle Eastern empire, which covered not only the Sumerian settlements, but also the northern lands of present-day Iran and Syria. The Akkadian period is historically important as it defines the period when the Sumerian city-states of southern Mesopotamia were first united. At that time in southern Mesopotamia, the increase in agricultural production led to a significant increase in population, whereas in the past city-states suffered from deprivation due to constant conflicts, which in turn increased the economic power of the region. ${ }^{5}$ Towards the end of the Akkadian Empire (2334-2154 BCE), competition between many city-states intensified and around 2200 BCE as the centralized political influence of the

1. A. Andrijauskas, Rytu Azijos tradicine estetika ir meno teorija (Vilnius: LKTI, 2017), 22-24.

2. P. J. E. Davies, W. B. Denny, F. F. Hofrichter, J. F. Jacobs, A. S. Roberts, et. al., Janson's History of Art: The Western Tradition. 8th Edition (London: Laurence King Publishing Ltd, 2010), 21.

3. J. R. Pournelle, "KLM to CORONA: A Bird's Eye View of Cultural Ecology and Early Mesopotamian Urbanization," in Settlement and Society: Essays Dedicated to Robert McCormick Adams (ed.) Elizabeth C. Stone (Cotsen Institute of Archaeology, UCLA and Oriental Institute of the University of Chicago, 2007), 29-62.

4. S. N. Kramer, The Sumerians: Their History, Culture and Character (Chicago: The University of Chicago Press, 1963).

5. A. Jamieson, “Empires of Ancient Mesopotamia," Agora 51, no. 3 (2016): 45-51. 
Akkadian dynasty weakened, power was shared by local leaders. At that time, the Akkadian Empire was tormented by an influx of nomadic Gutta tribes, and they eventually took over. However, the Gutian rulers were unable to cope with the subtleties of the empire's rule, so the years of their reign are called the Dark Ages. The lands of Mesopotamia were engulfed in chaos, and after a while, the foreigners were driven out by the newly emerging third dynasty of Ur, also known as the Neo-Sumerian Empire, but covering a much smaller territory. This short but striking period in Sumerian history is described by experts as the "Sumerian Renaissance." Around the time of the Neo-Sumerian Empire, archaeological data revealed traces of the Amorites of Semitic origin who spoke a language related to the one spoken by Akkadians but in a different dialect. This nation lead a seminomadic way of life, and a few centuries later finally overthrew the third Ur dynasty and began to dominate southern Mesopotamia. In the meantime, across the region, competition between individual cities and states which lasted for several centuries, is starting again. The Sumerians, who came under the influence of the Amorites of Canaan origin, never recovered politically, while in the free northern part of Mesopotamia the Assyrian rulers dominated the Akkadianspeaking population. At that time, in southern Mesopotamia, Babylon, first ruled by the Amorites and later by the Chaldeans, emerged. The dynamics between the two Akkadian speaking states led to the development of the entire region, until Mesopotamia was finally conquered by neighboring peoples of Iranian descent, ushering in a whole new cultural phase of civilization. The history of Assyria is divided into three periods, which correspond to the expansion of Assyria, accompanied by periods of contraction and decline (see Table 1). These are the Old Kingdom of Assyria (2000-1740 BCE), the Middle Assyrian period (13631056 BCE) and the Neo-Assyrian Empire (934-609 BCE). The Assyrians were primarily famous for their military power. The discovery of vast iron ore resources in their populated areas led to the emergence of an arms industry that allowed Assyria to have the best-armed military forces of its era. However, to ensure successful trade, the Assyrians established colonies in Asia Minor and established ties with the cities of Egypt, the Mediterranean, Anatolia, Iran, and the Caucasus, making their capitals a major intersection of trade routes in the Middle East. They have achieved a breakthrough in sculptural and architectural arts, which stand out with their unique stylistic features, and the maturity of their art forms. The Assyrians paid much attention to the development of the royal palaces, which symbolized their power, and they were richly decorated with reliefs of war and hunting glorifying the rulers. Many of their artistic features were taken over by the Persians who later dominated its territory. ${ }^{6}$

Meanwhile, the early phase of Babylon's life that was run by the Amorite rule was called the Old Kingdom of Babylon (19th-16th century BCE). It was followed by a dark period in which Babylon, weakened by the attacks of the growing Hittite kingdom, fell into the hands of the Kassites (XVI-XII century BCE). At that time, the Mesopotamian region was influenced by four hegemonies: Egypt; the Hittite Empire; Mitanni, enslaved by Assyria; and the Cassite Babylon, renamed

6. Andrijauskas, Civilizacijos istorijos metamorfozès: komparatyvistinis požiūris į neeuropini pasauli (Vilnius: LKTI, 2018). 
Karduniash. From the 12th century BCE, new waves of nomadic tribal migration began in Mesopotamia; it was so strong that scholars refer to it as the Aramaic Invasion. At this time, Babylon came under the rule of its eastern neighbors, the Elamites. However, the rise of the Central Assyrian kingdom halted further disintegration in the region. ${ }^{7}$ Even before the beginning of this expansion, these tribes were influenced by Mesopotamian culture for centuries and their governance forms and social organizations were similar, and therefore these processes did not affect the civilizational and cultural changes of Mesopotamia. ${ }^{8}$ In the 10th century BCE, Assyria was weakened briefly due to internal conflicts, but since 911 BCE thanks to the active ruler Adadnirari II, the Assyrian expansion resumed, leading to the third reunification of the region and the rise of the Neo-Assyrian Empire, whose rulers completely solved the so-called "Babylonian problem" and gained their independence. ${ }^{9}$ The Assyrian Empire was in a state of constant military conflict, which is thought to have followed, with the addition of internal divisions. Finally, in 612 BCE, Nabopolassar, the ruler of Chaldean descent, extended his influence to Babylon, and in the east, the charismatic leader Cyaxares, who united Persia and Medes, carried out an uprising by mutual agreement and divided the vast possessions of Assyria. Thus, New Babylon arose, also known as the Chaldea, which prospered until 539 BCE until the Achaemenid Persia took control of Mesopotamia. Babylon lost power for centuries, but it continued to appear as one of the most important provincial centers of the empire. The ruler of the Achaemenid Empire also had the traditional Mesopotamian titles of "King of Akkad and Sumer," "King of Babylon," and "King of the Four Worlds." When Alexander the Great occupied the region in 330 BCE, cuneiform was still used. Later, during the Hellenistic period, the cuneiform remained largely in the limited strata of the intelligentsia, whom still supported the ancient cults of Babylon and Uruk, which survived until the Muslim era. The last cuneiform record was made around $70 \mathrm{CE}$, ending a tradition that was flourishing for more than three millennia. ${ }^{10}$

7. D. Charpin, "The History of Ancient Mesopotamia: An Overview," in Civilizations of the Ancient Near East (ed.) J. Sasson et al., 807-829 (New York, 1995).

8. Andrijauskas, Civilizacijos istorijos metamorfozès: komparatyvistinis požiūris ị neeuropini pasauli, 2018, 70-76.

9. D. D. Luckenbill, The Annals of Sennacherib (Chicago: The University of Chicago Oriental Institute Publications, 1924).

10. Charpin, The History of Ancient Mesopotamia: An Overview," 1995. 
Table 1. The Evolution of the Civilizational Periods of Ancient Mesopotamia

\begin{tabular}{|c|c|}
\hline \multicolumn{2}{|c|}{ The first settlement of Eridu in about 5400 BCE } \\
\hline \multicolumn{2}{|c|}{ Uruk period 4100-2900 BCE } \\
\hline \multicolumn{2}{|c|}{ Sumerian Early Dynamic Period 2900 - 2350 BCE } \\
\hline \multicolumn{2}{|c|}{ Akkadian Empire - 2334-2154 BCE } \\
\hline \multicolumn{2}{|c|}{ Gutian rule period - XXIII-XXI BCE } \\
\hline Uro III, Neo-Sumerian Empire - 2047-1940 BCE \\
\hline Amorites rule period XX-XIX BCE & Ancient Kingdom of Assyria 2000-1740 \\
\hline $\begin{array}{c}\text { The ancient kingdom of Babylon in the } \\
\text { 19th-16th centuries BCE }\end{array}$ & Middle Assyrian period 1363-1056 BCE \\
\hline $\begin{array}{c}\text { Babylon of the Kassites in the 16th-12th } \\
\text { centuries BCE }\end{array}$ & \multicolumn{2}{|c|}{ Neo-Assyrian Empire 934-609 BCE } \\
\hline \multicolumn{2}{|c|}{ New Babylon, also called Chaldea, 612-539 BCE } \\
\hline
\end{tabular}

\section{Ancient Mesopotamian Gardens}

Recent archaeological and artistic research by scholars in various fields refutes the prevailing view that the ancient eastern countries developed under conditions of cultural isolation; on the contrary, they maintained close ties. This is evidenced by the material archeological monuments of culture and art, analogous art styles, aesthetic canons, cosmogonic myths, epics, motifs of light and radiance aesthetics. The Sumerian trade routes stretched incredibly wide, with economic and cultural ties with Egypt, India, and through the Orontes Valley and with Phenicia and Palestine. It is obvious that Mesopotamia was located at the center of cultural interactions between these ancient eastern countries --it was the place where the original mythological archetypes were formed, such as the ocean of creation, the flood, the gardens of paradise, the golden age of mankind, and many others. A lot of elements of the Sumerian worldview undoubtedly influenced the formation of biblical Hebrew texts, and thus the spread of all cultural spaces covered by Abrahamic religions. ${ }^{11}$ One of the fundamental images that was formed in ancient Mesopotamia and reached our time, is that of the gardens of paradise. The Greeks used the Persian word "paradeisos" to describe the enclosure, the garden, the orchard, and the Eden garden of paradise. The famous Sumerian researcher S. N. Kramer observes that, although the divine gardens found in the myths of the Sumerians (and later the Babylonians), Dilmun, are inhabited only by the gods, and have many parallels with the later common images of paradise gardens, so they can be treated as the origins of the latter. Important here are the motives of the gardens, their implied location, fruit-eating, subsequent death, ribs, and painless childbirth, which, according to Kramer, it later transformed into a Semitic worldview. ${ }^{12}$ Clearly, the idea of an enclosed space is fundamental to the gardens

11. Andrijauskas, Rytu Azijos tradicine estetika ir meno teorija, 2017.

12. Kramer, The Sumerians: Their History, Culture and Character, 1963. 
of ancient Mesopotamia, and the tree of life in the biblical gardens of paradise from which the four rivers flow, including the Tigris and the Euphrates, which occupy an important place. The tree, taken together, was the most important compositional element of the garden. ${ }^{13}$

Very little is known about early period gardens or ornamental water use, as these elements change the most over time and survived the shortest period of time compared to architecture, sculpture, or other archaeological heritage. ${ }^{14} \mathrm{M}$. Laurie argues that the origins of orchards must be derived from agricultural practices, and that the first fenced orchards may be associated with primary garden prototypes and therefore the beds, shapes, and dimensions of these orchards corresponded to the parameters of the cultivated fields. Irrigation canals and ponds, in these primary gardens, were integrated not only for functional purposes, but also for sensory pleasures to enjoy the water in the hot climate. To protect crops and gardens from the scorching sun and dry winds, the Sumerians planted them, providing shelter and shade with a tree strip (Figure 1) that was irrigated with confusing canals, and the Sumerian gardens were walled to keep away wild and domestic animals and insects. ${ }^{15}$ Such walled gardens have been found in many ancient Mesopotamian cities of various periods: Uruk, Mari, Babylon, and Nineveh. ${ }^{16}$ The gardens of the city of Uruk are described in the Sumerian mythical "Epic of Gilgamesh," where it is stated that one-third of the city consisted of a residential urban area, one-third of cultivated fields and the remaining third of gardens. However, it is not very clear which specific gardens are involved, as the early Sumerian word describing gardens applies to both conventional and orchard gardens. ${ }^{17}$

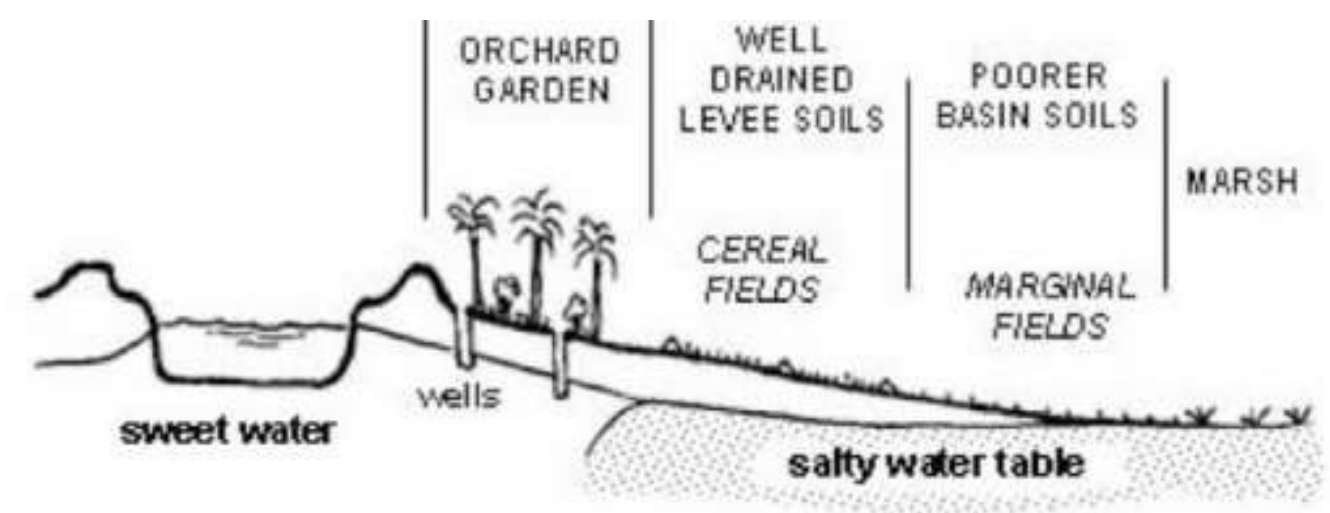

Figure 1. Hypothetical Southern Mesopotamian Agricultural Cell Layout Source: Mays, 2010, 47.

13. D. P. Patrick, The Imperial Gardens of Mesopotamia: Landscapes of Power. 2016. Retrieved from: https://bit.ly/3iG8laA. [Accessed 30 March 2021.].

14. C. S. Campbell, Water in Landscape Architecture (New York: Van Nostrand Reinhold Company, 1978), 15.

15. M. Laurie, An Introduction to Landscape Architecture (Elsevier, 1986), 17.

16. C. Girot, The Course of Landscape Architecture (Thames \& Hudson, 2016), 53.

17. G. A. Jellicoe and S. Jellicoe, The Landscape of Man: Shaping the Environment from Prehistory to the Present Day (Thames and Hudson, 1995), 24. 
Not surprisingly, in the Sumerian civilization space, complex pipelines and sanitary facilities were also found, and the cities had developed waste water and rainwater drainage technologies. Habuba Kabira, a short-lived Sumerian trade colony in northern Mesopotamia that has been discovered by archaeologists, was built in the city in the mid-fourth millennium BCE. It had a particularly complex sanitary system, with various pipes, drains and even toilets. There is no doubt that the settlement was built with prior knowledge based on the technology and design used in the central city of the metropolitan city of Uruk. It is far more surprising to researchers that these advanced sanitary technologies have become forgotten over time. ${ }^{18}$ It is therefore not surprising that the first known aesthetic water facilities were also found in the civilized space of Mesopotamia. The oldest surviving cascades were located in Girsu (3000 BCE). The cascades consisted of water basins which were decorated with carvings. Water was going in thin pipes set in a downward stepped system until it reached the lowest basin that was decorated with a lion head. Another important find that was unearthed in Mari and dating back to the Akkadian-Sumer period, is a figure of a woman with a jug of water that dates back to 2000 BCE. Water was piped to the jug, and the bursting water can be considered the earliest known prototype of a fountain (Figure 2). The researchers associate this figure with the goddess of fertility and political power, Ishtara. ${ }^{19}$

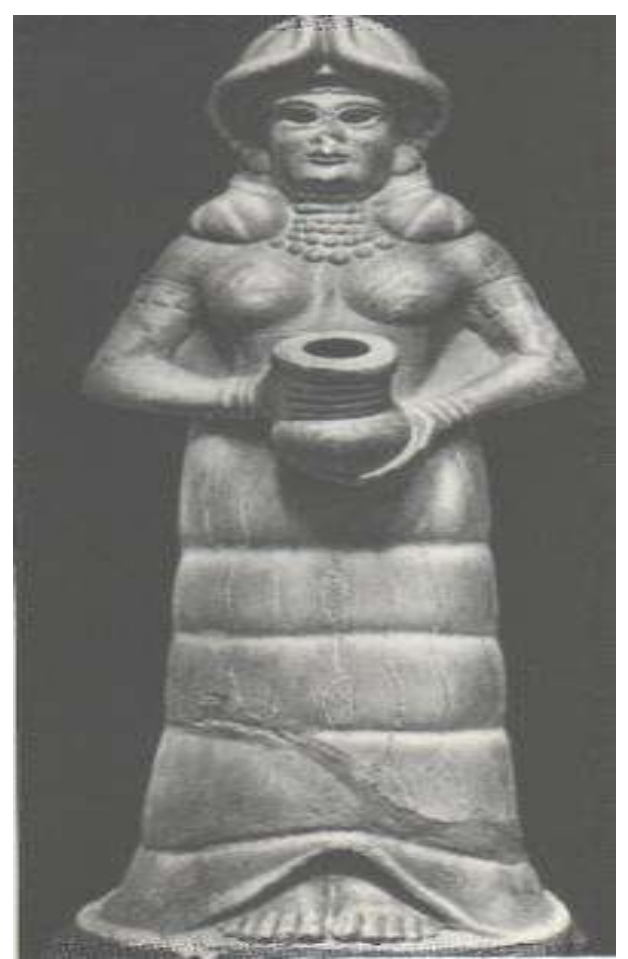

Figure 2. Mesopotamian Stone Fountain Figure, 2000 BC Source: Plumptre, 1993, 19.

18. L. W. Mays, Ancient Water Technologies (Dordrecht, Heidelberg, London, New York: Springer, 2010), 38-42.

19. G. Plumptre, The Water Garden - Styles, Designs and Visions (Thames \& Hudson Ltd., 1993), 19; Girot, The Course of Landscape Architecture, 2016, 51. Britannica, Retrieved from: https://www.britannica.com/art/fountain/. [Accessed 30 March 2021.] 
Located in the middle of the Euphrates, one of the largest courtyard gardens in Mesopotamia was also found. The tracks in these gardens were based on terracotta, fired clay bricks, and traditionally they were raised slightly above the yard surface to keep them from dusting. It is known from written sources that the palace had several gardeners and that the rulers often had snacks in their gardens. These gardens were planted with palm trees and had an ornamental pool. The pool, though, was not usually built in the center, but a little to the side. At the center was, in ancient Mesopotamia, a much more significant element -- the tree. ${ }^{20}$

According to one of the earliest written sources, gardens in southern Mesopotamia have been regular since Sumerian times. These gardens, dating back to the fourth millennium BCE, like the later Babylonian gardens, were based on ritual and economic incentives. In Mesopotamia, gardens were always associated with a sacred place, with links to economics, magic, poetry, and religion. The early functions of gardens were to give rulers a proper place to participate in religious rituals. It is known that the gardens were also a stage for cult ceremonies, such as the New Year Festival, and at the same time functioned as industrial harvest suppliers. Although both functions were associated with kings, it is difficult to determine whether the same places were used for both of these purposes, and whether the rituals occupied separate gardens. There is also not enough data to reconstruct the layout or appearance of these gardens, making it very difficult to estimate gardens from the fourth to mid-millennium BCE. ${ }^{21}$ However, since the time of the Middle Assyrian Kingdom, there are far more written, archaeological and iconographic sources. Like many other cultural and ritual aspects of Mesopotamia and Babylon, the Assyrians absorbed many traditions and cult rites. $^{22}$ The ruler of the Neo-Assyrian Empire, Sennacherib (705-681 BCE), built a temple for the New Year Festival (Figure 3) outside of Nineveh. Archaeological excavations have also revealed traces of the layout of the gardens belonging to this rectangular temple. After a thorough examination of the planting pits found, it was still not possible to identify which trees or shrubs grew there. In the central inner courtyard, and outside it, plantings were planted at regular intervals on all sides. From the point of view of the scientist S. Dalley, although archeological excavations have reconstructed the plants as shrubs, it could also have been the trees of thin stems, giving the temple an impression among the grove. ${ }^{23} \mathrm{~A}$. Asadpor also notes Sennacherib's records, claiming that he dug two irrigation canals for the temple and planted it in orchards. ${ }^{24}$ However, archaeological research reveals that the planting pits on the outside of the temple were irrigated with irrigation pipelines, confirming that the temple was surrounded by permanent

20. S. Dalley, "Ancient Mesopotamian Gardens and the Identification of the Hanging Gardens of Babylon," Garden History 21, no. 1 (1993); P. Taylor (Ed.), The Oxford Companion to the Garden (Oxford University Press, 2006), 308-309.

21. A. Amrhein, "Neo-Assyrian Gardens: A Spectrum of Artificiality, Sacrality and Accessibility," in Studies in the History of Gardens \& Designed Landscapes, 91-114 (2015).

22. Patrick, The Imperial Gardens of Mesopotamia: Landscapes of Power, 2016, 32.

23. Dalley, "Ancient Mesopotamian Gardens and the Identification of the Hanging Gardens of Babylon," 1993.

24. A. Asadpor, "Phenomenology of Garden in Assyrian Documents and Reliefs; Concepts and Types," Bagh-e Nazar 15, no. 60 (2018): 55-66. 
gardens. However, the planting pits in the courtyard garden were not connected to the piping system, which suggests that the trees were planted here on designated occasions for ritual purposes. The rebuilding of the trees and their non-permanent installation, as well as the temporary exposition, clearly testify to the decorative nature of the aesthetics of these gardens. Various written sources also claim that the trees were sacrificed to the gods, and various cylindrical imprints describe the transportation of the trees in pots or baskets. ${ }^{25}$ Using the oldest-known archeological example of temple gardens, it can be said that the courtyards of the temples, like the courtyards of the palace, were used for gardening. Still, the researchers note that comparing the northern Assyrian temples with the southern Babylonian ones, it is clear that the Babylonian temples owned much more land around them, and those lands were divided and successively supplied various crops, especially dates, figs, and pomegranates, for cult purposes. ${ }^{26}$
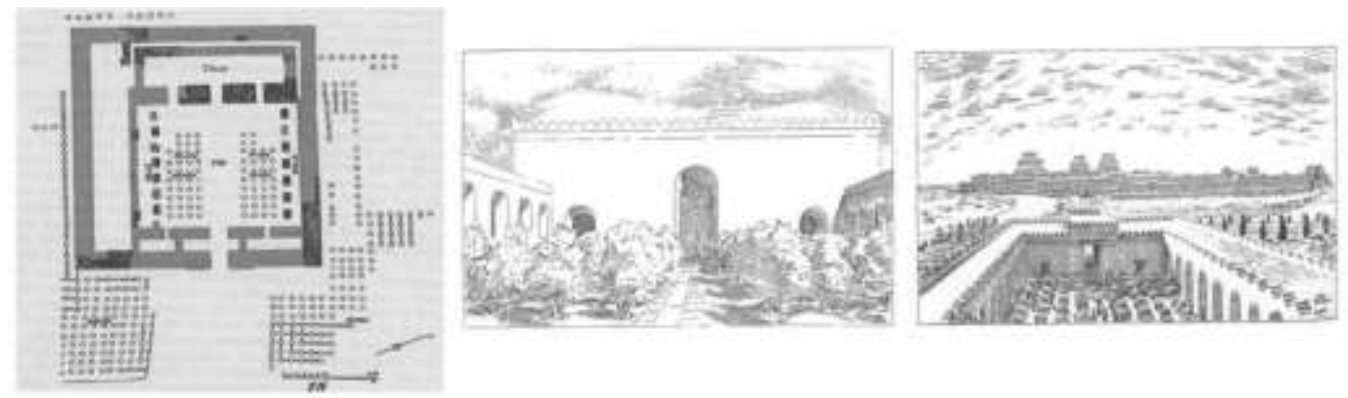

Figure 3. New Year's Festival Temple, Archaeological Findings and Reconstructive Visualizations

Source: Amrhein, 2015, 97.

Many ancient Mesopotamian temples were found decorated with columns imitating the trunks of date palms or a spiral trunk palm with inedible fruit, possibly Chamaerops humilis. The facades of the temples were also decorated in a similar manner. Using the deduction method, researchers make strong assumptions that the architectural form and decor given to some urban and suburban temples was intended to symbolize the environment of a sacred grove in a garden of paradise. $^{27}$ Temple gardens, or those adjacent to the temples, were given more attention to appearance, their smell, and the shadow they provided, as they were designed to convey the city's fame and prestige. ${ }^{28}$ The records of Esarhaddon (681-669 BCE), the ruler of the Assyrians, describe the garden of the temple at Babylon, which had water canals, fruit trees and bearing beds. From the record of King Merodach-Baladan II (721-710 BCE and 703 BCE), a record of plants found in the royal gardens of Babylon reaches us from the briefly regained independence of Babylon, the reign of the Neo-Assyrian Empire. The records of another ruler,

25. Amrhein, "Neo-Assyrian Gardens: A Spectrum of Artificiality, Sacrality and Accessibility," 2015.

26. Dalley, "Ancient Mesopotamian Gardens and the Identification of the Hanging Gardens of Babylon," 1993.

27. Ibid.

28. Patrick, The Imperial Gardens of Mesopotamia: Landscapes of Power, 2016, 34. 
Nebuchadnezzar II, reveal that he grew fruits and vegetables as sacrifices to the gods, but imported grapes and raisins because the grapes did not ripen in southern Mesopotamia. Still, researchers do not find evidence or other data on former Assyrian-style public parks or hunting gardens in southern Mesopotamia. ${ }^{29}$ However, the Babylonian royal palace gardens (Kiril ekaliim) were already mentioned during the reign of Adad-suma-usur (1200-1180 BCE), and are reaffirmed in later records. The temple gardens in Babylon have been known ever since the reign of the Kassites, from the 16 th century BCE. ${ }^{30}$

In earlier centuries, during the time of the Neo Sumerian Empire, the region was united by King Ur-Nammu, the ruler of Ur. He is known for producing one of the first written acquis, restoring order, stabilizing the economy, and bringing back the Sumerian language. ${ }^{31}$ During the reign of Ur-Nammu, the greatest surviving Sumerian monument was erected -- the Great Ziggurat of Ur-- which dates back to $2250 \mathrm{BCE}$; it caused quite a considerable fuss in our times. Initially, when this monument was unearthed, it was wrongly assumed that its terraces were planted with ornamental plants, although this was soon refuted. ${ }^{32}$ However, this false statement is widespread and is still accepted after almost a century, based on the popular reconstructions of the Ziggurat of Ur presented by L. Woolley, and the presumed assumptions of mystical hanging gardens. S. Dalley explains that when archaeologist. L. Woolley excavated the ziggurat, he saw that it was composed of silt bricks and the outer layer was covered with burnt clay bricks, but the entire structure was perforated at regular intervals with holes that penetrated through masonry. Wooley interpreted these openings as drainage, but after a few more ziggurats had been excavated, researchers confirmed that the towers were not actually planted with trees or shrubs. S. Dalley argues that it was practically impossible to supply such greenery with the required amount of water without washing the sludge brick building. The openings were in fact intended to ventilate this structure in order to dry the structure so that it would not later decompose or collapse. ${ }^{33}$ It is noteworthy that over time, some ziggurats broke and actually collapsed, and later such dilapidated structures in the eyes of contemporary Israelites may have provided the basis for the development of the myth of the collapse of the Tower of Babel. ${ }^{34}$

\section{Hanging (Terraced) Gardens of Babylon}

In later times, during the reign of the New Babylonian kingdom, ruled by the Chaldean dynasties, Babylon became an influential Ancient World city, distinguished by the distinctive Babylonian stylistic aesthetics of architecture,

29. Taylor (Ed.), The Oxford Companion to the Garden, 2006, 309.

30. D. J. Wiseman, "Mesopotamian Gardens," Anatolian Studies 33 (1983): 138.

31. Jamieson, "Empires of Ancient Mesopotamia," 2016.

32. Taylor (Ed.), The Oxford Companion to the Garden, 2006, 308.

33. Dalley, "Ancient Mesopotamian Gardens and the Identification of the Hanging Gardens of Babylon," 1993, 6.

34. E. R. Rogers, Landscape Design: A Cultural and Architectural History (Abrams, 2001), 35. 
sculpture and decor. Like the pre-dominated Assyrians, the Chaldeans also built monumental, astonishing architectural buildings on their scales, creating magnificent temples and palaces, ruled gardens, and surrounded the city with strong and impressive defensive walls. ${ }^{35}$ Babylon was founded after one of the regular changes in the course of the Euphrates River bed, but the river acquired its now characteristic curvature around the 7th century BCE, during the New Babylonian period, when, for militaristic needs, three artificial bends and a huge artificial lake in the upper reaches were dug, according to Herodotus' testimony. ${ }^{36}$ The ruins of the Old Babylonian city had unfortunately been washed away by the Euphrates, due to the constant rise in water levels, and now only the ruins of the New Babylonian city are known. ${ }^{37}$ During this period, a unique Ishtar Gate, reinforced with heavy portals, with column-reinforced frames and bronze doors was also built. The legendary Tower of Babel was rebuilt from which only a large foundation has survived -- the base remains, and the representative buildings are no longer embossed with colored-glazed bricks. ${ }^{38}$ Babylonian culture has traditionally nurtured temple gardens, and there were lots of them in Babylon dedicated to various gods and rites. Scholars know that the Babylonian gardens, which raised the prestige of the city, were renovated during the New Babylonian period. ${ }^{39}$ Traditionally, the legendary "Hanging Gardens" are also attributed to Babylon of this period. At different times attempts have been made to create different visual representations of these gardens. A cycle in 1572 painted by Dutch artist Maarten van Heemskerck described seven wonders of the world. The artist's interpretation of these gardens met the aesthetic requirements of the time but relied more on the author's imagination than on real facts (Figure 4). However, later in the 17th century in Germany, the Jesuit Athanasius Kircher, a famous scholar of his time, referred to classical texts and the scientific knowledge, and presented a much more realistic version (Figure 5). ${ }^{40}$ However, not all written sources attribute the construction of the latter to Babylon and its ruler Nebuchadnezzar II; some claim authorship of the kings of Assyria as well, so in recent years it has been hypothesized that these gardens may not have existed in Babylon, but actually were found in the Assyrian capital, Nineveh. Archaeological excavations have not yet confirmed the presence of these gardens in Babylon either, so scientists have several assumptions. One of them states that hanging gardens did not exist at all, and the surviving descriptions represented Mesopotamian gardens in general as such. ${ }^{41}$ Another common hypothesis is that classical sources have somewhat

35. Andrijauskas, Rytu Azijos tradicine estetika ir meno teorija, 2017.

36. Jellicoe and Jellicoe, The Landscape of Man: Shaping the Environment from Prehistory to the Present Day, 1995, 27.

37. J. J. Mark, Babylon, 2011. Retrieved from: https://www.ancient.eu/babylon/. [Accessed 30 March 2021.]

38. Andrijauskas, Civilizacijos istorijos metamorfozès: komparatyvistinis požiūris ị neeuropinị pasauli, 2018, 73 .

39. Wiseman, "Mesopotamian Gardens," 1983, 138.

40. The Gardens of Babylon. Retrieved from: https://www.wonders-of-the-world.net/Seven/ Gardens-of-Babylon.php/. [Accessed 30 March 2021.].

41. W. H. Jr. Stiebing and S. N. Helft, Ancient Near Eastern History and Culture (Routledge, 2017). 
exaggerated and misinterpreted existing Babylonian buildings when describing these gardens. A proponent of this hypothesis, D. Wiseman, ${ }^{42}$ argues that the terrestrial structures between the Euphrates (which possibly supplied water to these structures) and the Southern Palace were documented in ancient cylinders and were interpreted as hanging gardens (Figure 6). However, critics note that the Euphrates bed had changed again from those times until the period of the classical springs that reached us, and irrigating such gardens at the south gate would have been very impractical. ${ }^{43}$

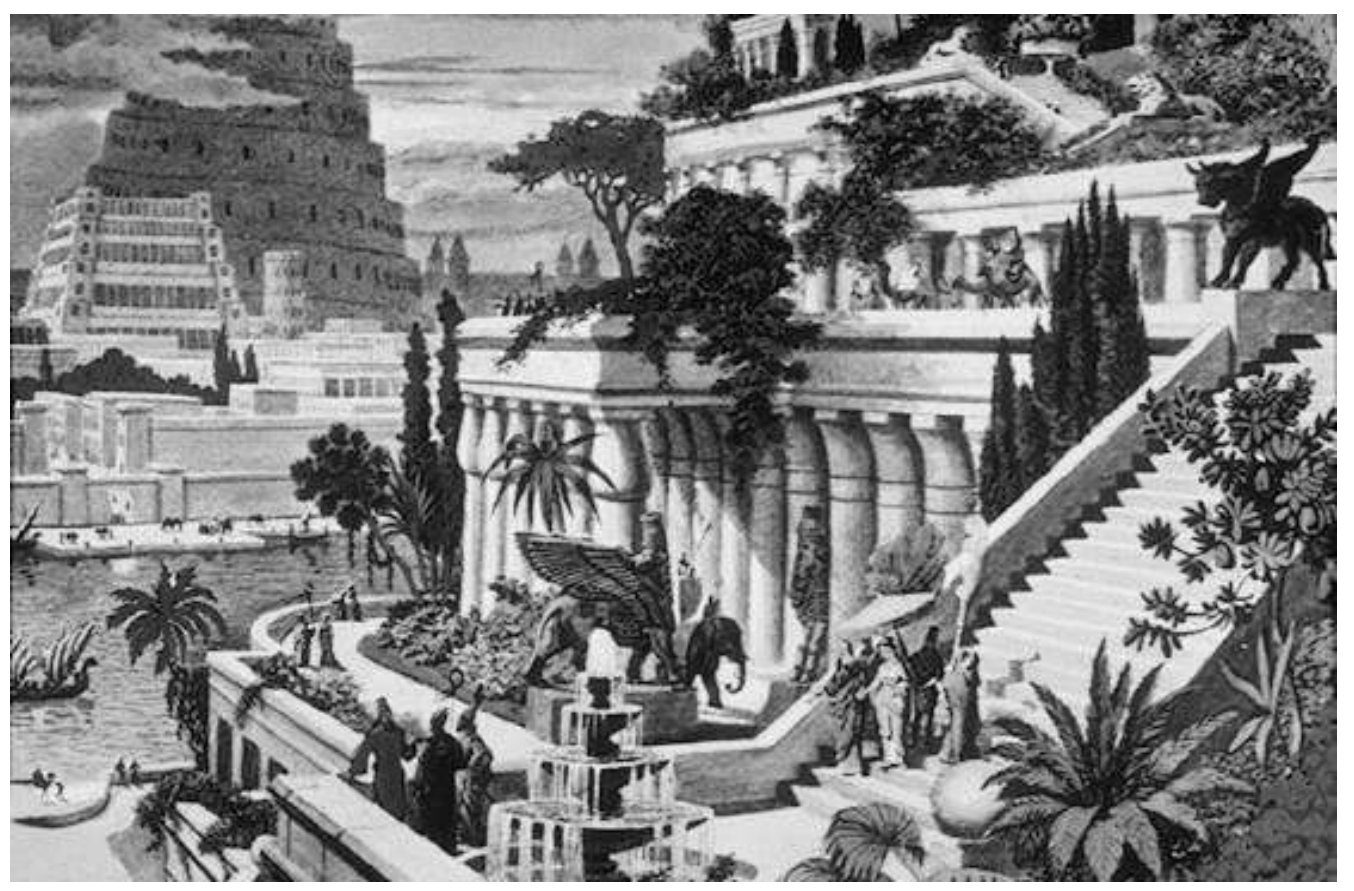

Figure 4. Maarten van Heemskerck (1498-1574) - "Hanging Gardens of Babylon" - Engraving-1572, Based on the Author's Imagination, a Widespread Visualization of Hanging Gardens

Source: http://viticodevagamundo.blogspot.com/2011/02/seven-wonders-of-ancient-world-sete.html. [Accessed 30 March /2021.]

42. Wiseman, "Mesopotamian Gardens," 1983.

43. Stiebing and Helft, Ancient Near Eastern History and Culture, 2017. 


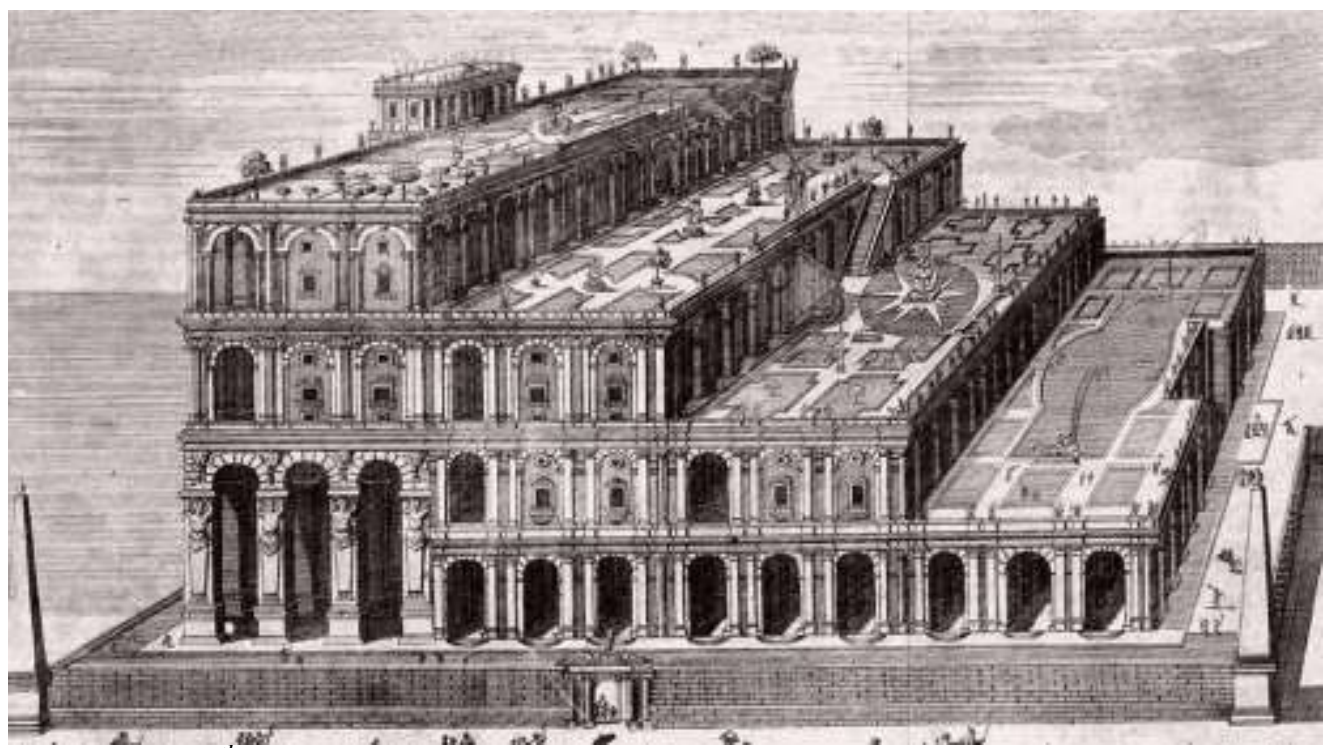

Figure 5. $17^{\text {th }}$ Century Visualization Based on Literature Interpretation by Jesuit Athanasius Kircher

Source: https://www.wonders-of-the-world.net/Seven/Gardens-of-Babylon.php. [Accessed 30 March 2021.]

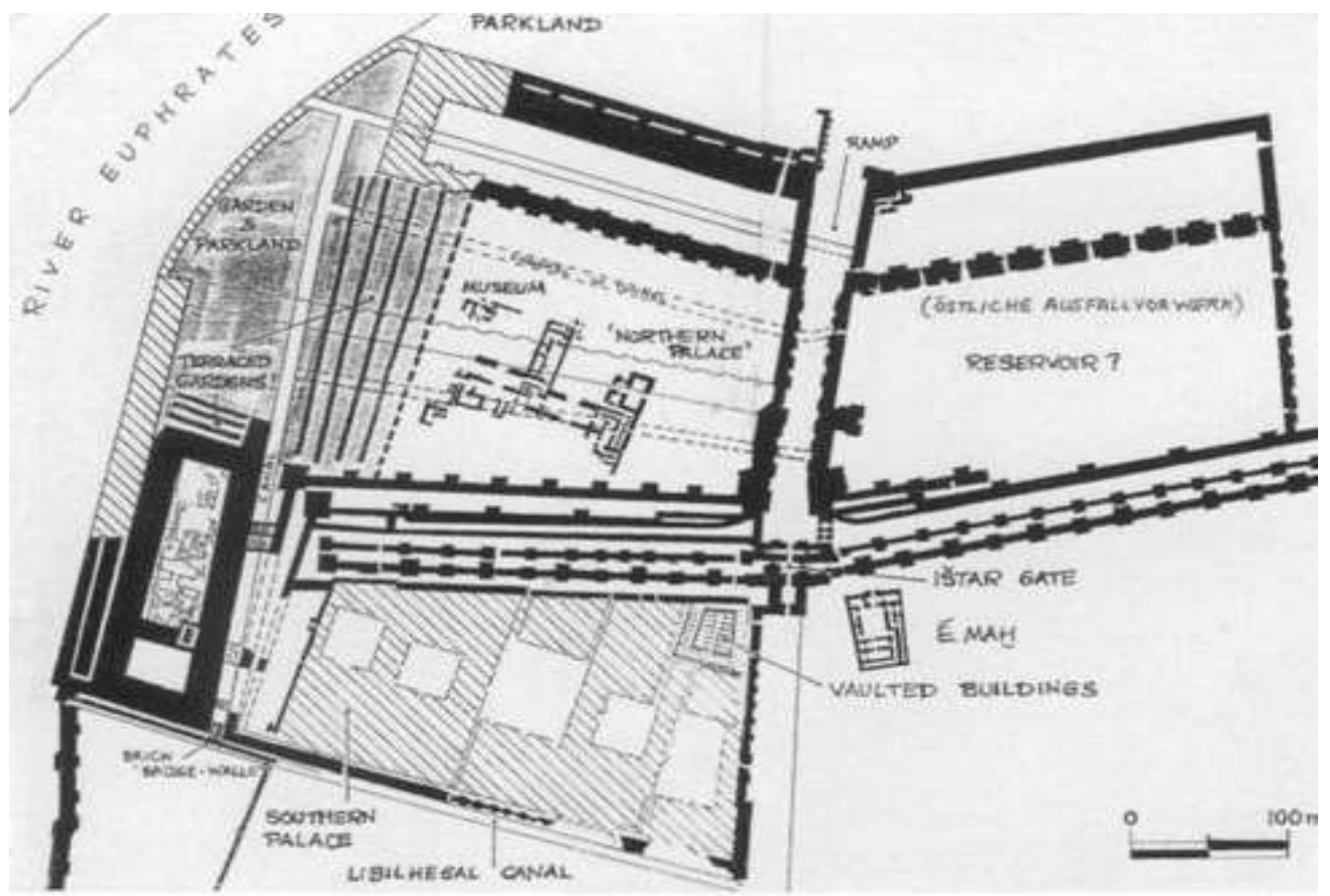

Figure 6. Wiseman's suggested Location for the Hanging Gardens of Babylon Source: Wiseman, 1983, 144.

\section{Gardens of the Assyrian Empire}

Much more knowledge about the gardens of ancient Mesopotamia comes from the Assyrian Empire. As the Assyrians originated from the plains, it also led 
to changes in landscape architecture, much freer garden layout, and imitation of natural nature. They are characterized by hunting parks enriched with cedars and other imported trees, as well as exotic animals brought from conquered lands or donated by rulers of distant lands. It is assumed that since 2000 BCE the kings of Mesopotamia held exotic animals and plants in separate parks. These parks were further away from the palace of the rulers or even outside the city walls. One of the most impressive parks was owned by the ruler Tiglath-Pileser I (1115-1074 BCE), who, according to his royal records, bred herds of horses, cattle, donkeys, gazelles, various species of deer and mountain goats, and planted a hunting garden in cedar, beech, oak, and exotic fruit trees, and also had a crocodile and a large monkey. ${ }^{44}$ These hunting gardens were called "ambassu" and were associated with kings, gods and rituals, and were somewhat open to the general public. Ritual hunting of lions took place in these places. These parks were less artificial and more naturalistic, as they mimicked the wild areas inhabited by lions. The hunts that took place here were for public viewing and were heavily staged. Successful hunting was associated with the re-establishment of the king's divine support for ruling force and reign, as well as the triumph of the Assyrian civilization. ${ }^{45}$ Animals and plants from different countries collected in these gardens were designed to represent the whole known world. ${ }^{46}$

Over time, expressing their royal ideology, the rulers of Assyria began to build much larger gardens, and paid more attention to their layout and design. The king of the Neo-Assyrian Empire, Ashurnasirpal II (883-859 BCE), initiated huge water management projects and brought water from the hills and mountains to irrigate his newly planted city orchards in his new capital, Nimrud (also known as Kalhu). From the upper part of the Zab River in the mountains, water was diverted to the rocks through channels carved into the rocks. ${ }^{47}$ His own records were found where he says that waters around these gardens get into the canal and then into the gardens from above. ${ }^{48}$ Ashurnasirpal II called these gardens near his new capital Nimrud, "kiri rishate" - "the garden of pleasure." Here he planted 41 different species of trees, and also kept several different species of animals, suggesting that these gardens were fenced. These gardens, according to the ruler who implemented them, were for the enjoyment of the Assyrian people, while Tiglath-Pileser I said of his gardens that they were built exclusively for the joy of the king (for himself in this matter). However, at that time, the dichotomy of state and religion did not exist and therefore no great distinction could be made between royal and divine gardens, as in their worldview all aspects of life were associated with gods and cult. In an effort to imitate divine gardens, royal gardens were characterized by greater decorativeness, artificiality, introversion, and ritual activity. These gardens

44. Dalley, "Ancient Mesopotamian Gardens and the Identification of the Hanging Gardens of Babylon," 1993; Taylor (Ed.), The Oxford Companion to the Garden, 2006, 308.

45. Amrhein, "Neo-Assyrian Gardens: A Spectrum of Artificiality, Sacrality and Accessibility," 2015.

46. M. Novak, "From Ashur to Nineveh: The Assyrian Town-Planning Programme," in Papers of XLIXe Rencontre Assyriologique Internationale 1 (Iraq 66), London, 2004, 181.

47. Taylor (Ed.), The Oxford Companion to the Garden, 2006, 308.

48. Dalley, "Ancient Mesopotamian Gardens and the Identification of the Hanging Gardens of Babylon," 1993. 
covered an area of $25 \mathrm{~km}^{2}$ and, for the first time in Assyria, were equipped with a panoramic platform connecting with the palace to gaze the view of the gardens. The term "bitumen" is used to describe this construction. These platforms were used not only for royal purposes, but also for ritual cult needs. There were porticoes and columns surrounding the facades, and it has been thought to have been adapted from the architecture of the Syrian-Hittite palace. ${ }^{49}$ It is the first architectural element used in the Assyrian gardens that enabled visual communication between architecture and the landscape. ${ }^{50}$ Interestingly, crypts of queens' graves are also found under the courtyard gardens of the Royal Palace in Nimrud. Thus, these gardens may have also functioned as memorial. ${ }^{51}$

Undoubtedly, the art of the Assyrian gardens and the conceptual worldview that accompanies it, judging by archaeological, literary, iconographic and culturalhistorical research, were developed during the Sargon dynasty (722-609 BCE). It is probable that until then, most of the Assyrian gardens, in addition to their size, did not have highly-developed stylistic forms; the most striking feature of which was the terraces. During the Sargon Dynasty period, royal gardens were built outside of the palace, and were located alongside their walls. The terminology has also changed, as L. Oppenheim notes, where before that period the garden was called kiru, but it evolved into kirimahhu, meaning "large or glorious garden." This word is a Sumerian debt to emphasize the prestige of gardening as an ancient heritage. ${ }^{52}$ Along with the name, the concept of gardens changed during the reign of Sargon II, and later of his son Sennacherib, when gardens changed their traditional, somewhat "utilitarian" function to a more predominant exposition assignment. ${ }^{53}$ In Dur-Sharrukin, the new capital of Sargon II, a relief depicting a king resting in his gardens, near a pond and an artificial hill (c. 715 BCE) (Figure 7 ), is one of the earliest works of landscape style art. ${ }^{54}$ Regularly planted dates grew in these royal gardens, which were also planted along the canals, along with a wide variety of fruit trees such as apples, figs, peaches, plums, cherries, and pomegranates. ${ }^{55}$ Sargon II copied the model of the old capital, Nimrud, and all the characteristic elements in creating his new city. However, the layout of the city was almost an ideal square, and, as a result, it was far more regular in shape and geometric layout than other Assyrian cities. The main highlight here was the fortified citadel, which housed the public buildings--most prominently highlighted by the palace of the rulers--which extends beyond the citadel, thus breaking down the square layout and providing greater contrast. The palace, seen from the city side, was visible from three sides (Figure 8). Unlike in Nimrud, the main visual

49. Amrhein, "Neo-Assyrian Gardens: A Spectrum of Artificiality, Sacrality and Accessibility," 2015.

50. Patrick, The Imperial Gardens of Mesopotamia: Landscapes of Power, 2016, 34.

51. Dalley, "Ancient Mesopotamian Gardens and the Identification of the Hanging Gardens of Babylon," 1993.

52. Amrhein, "Neo-Assyrian Gardens: A Spectrum of Artificiality, Sacrality and Accessibility," 2015.

53. Patrick, The Imperial Gardens of Mesopotamia: Landscapes of Power, 2016, 33.

54. Jellicoe and Jellicoe, The Landscape of Man: Shaping the Environment from Prehistory to the Present Day, 1995, 27.

55. Rogers, Landscape Design: A Cultural and Architectural History, 2001, 39. 
highlight of Dur- Sharrukin was no longer the temple, but the royal palace. On the other side of the palace were the royal gardens, which, as can be seen from the reliefs, also housed "bitanu" observation pavilions, artificial mountains, and ponds with boats. ${ }^{56}$ Ponds, at the latest time since the time of Sargon II, have become a common feature of the Assyrian royal gardens. ${ }^{57}$

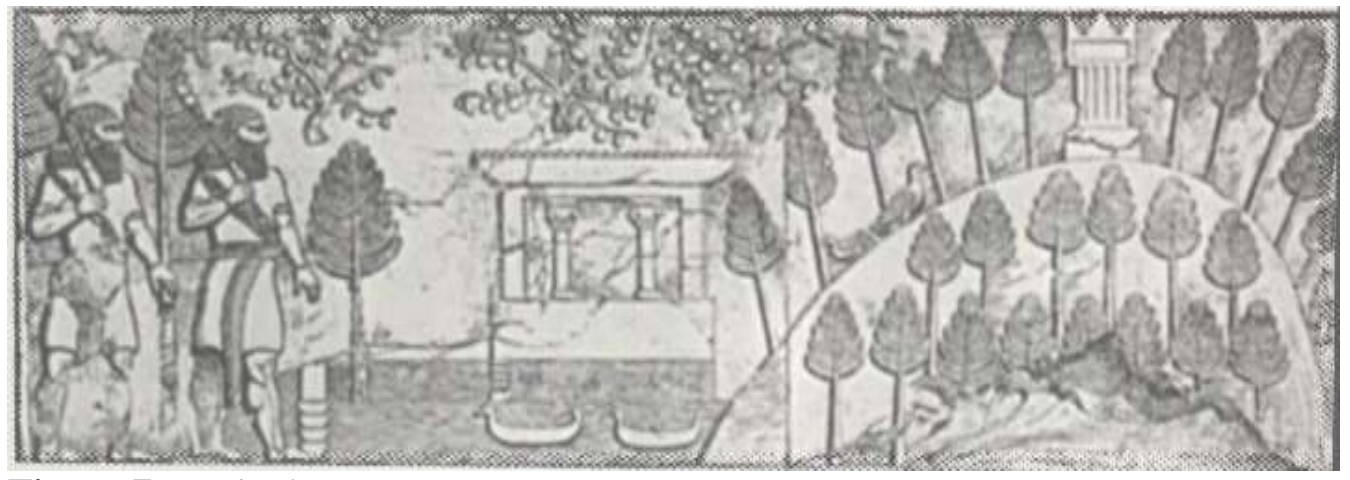

Figure 7. Park of Sargon II

Source: Jellicoe and Jellicoe, 1995, 27.

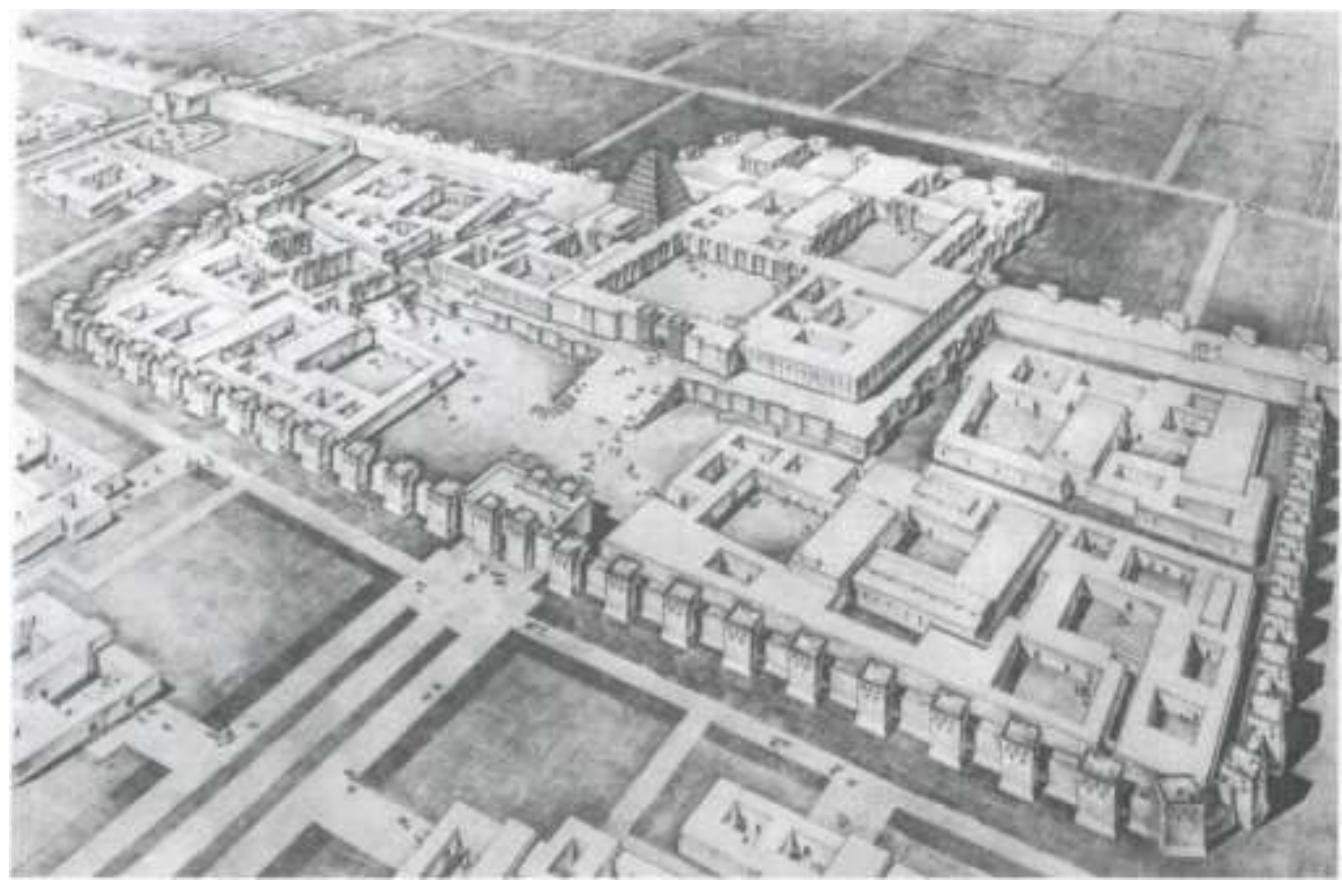

Figure 8. Reconstruction of the Dur-Sharrukin Citadel with a Palace

Source: Novak, 2004, 181-182.

Sargon's son Sennacherib (704-681 BCE) also developed gardens, and during his reign the gardens became a particularly prominent and characteristic part of the

56. Novak, "From Ashur to Nineveh: The Assyrian Town-Planning Programme," 2004, 181182.

57. P. Albenda, “Grapevines in Ashurbanipal's Garden," Bulletin of the American Schools of Oriental Research no. 215 (1974), 6. 
Assyrian landscape. Again, he moved the capital of Assyria to the pre-existing city of Nineveh, rebuilt and expanded it, surrounded by two walls, and planted gardens both inside and outside the city, probably for the sake of a more convenient and problematic water supply in Dur-Sharrukin. The two artificial mounds--mounds in the river crossing the city-- were transformed into powerful citadels. The basic urban structure used for the transformation of the city was taken over from the former capitals Nimrud and Dur-Sharrukin. At the top of the main, larger citadel closer to the edge, the Royal Palace of Sennacherib was built, overlooking the riverbank and gardens, and later on the sides and the palace of his grandson Ashurnasir-pal II (668-627 BCE), with temple buildings in the center. Due to its positioning, the facade of the royal palace was visible from outside the city. This largest and last capital of the empire reveals the culmination of the development of urban planning in Assyria, and the growing importance of urban elements, namely citadels, fortifications, and royal gardens, in the architecture of the time. ${ }^{58}$ Significant New Year Festival temple gardens were found outside the city, by the river valley. These are the best archaeologically-preserved temple-type gardens in Mesopotamia, where semi-public ceremonies for the elite took place. The New Year Festival was a very important cultural and ideological celebration, enshrining the symbolism of the king and his reign, and unity with the god Ashur. ${ }^{59}$ Hunting and play gardens were also set up outside the city walls--those were ambassu-type gardens-- some on the north side of the Adad Gate and the others east of the Shamash Gate. Ritual hunts were held here, and judging by the reliefs of the later ruler Ashur-nasir-pal II, military exercises were also organized in these gardens. These gardens, as usual, were looser structures to mimic chaos-dominated wildlife. The other part of the city's land was also used for public purposes; the plots were designed for growing trees and vegetables and divided for the people of Nineveh. It is not known exactly what was grown in these private gardens, but Sennacherib left a record assigning them to human health and joy, giving them an individual source of food. Many of these gardens were distributed to high-ranking officials who generated income from them. ${ }^{60}$ Finally, in the northern part of the city, there were also public gardens and orchards, which were also used for harvesting and were thought to have little cultic significance and were therefore poorly developed stylistically. But here, too, public, landscaped observation platforms were also found from which the entire city and its visual structure were to be seen, thus symbolically showing the viewer the full grandeur of the Assyrian Empire. ${ }^{61}$ For its ambitious projects from the mountains, Sennacherib brought waters to its new capital, and with the help of canals and aqueducts, the surviving ruins are still visible today. He initiated impressive canals, which in some places reached $80 \mathrm{~m}$ area and $20 \mathrm{~m}$ depth, according to data collected by researchers. The construction 182.

58. Novak, "From Ashur to Nineveh: The Assyrian Town-Planning Programme," 2004, 181-

59. Amrhein, "Neo-Assyrian Gardens: A Spectrum of Artificiality, Sacrality and Accessibility," 2015.

60. Patrick, The Imperial Gardens of Mesopotamia: Landscapes of Power, 2016, 35-43.

61. Amrhein, "Neo-Assyrian Gardens: A Spectrum of Artificiality, Sacrality and Accessibility," 2015. 
of the canals underwent four stages: first implementation of the Kisiri Canal, 13.4 $\mathrm{km}, 702 \mathrm{BCE}$; the system was later supplemented by the Musri mountain canal, which collects spring and basin waters, in 694 BC; then the Northern System was created, $46.4 \mathrm{~km}, 690 \mathrm{BCE}$; and finally, the ambitious Khinnis system, $55 \mathrm{~km}$, 690-688 BCE. Khinnis, the latest water supply system, consisted of canals and tunnels, and as the city crossed the lowlands, water reached the aid of an aqueduct. It consisted of 6 columns -- pillars, had breakwaters and lasted for $280 \mathrm{~m}$. To Sennacherib's pride, innovative automatic water slides were also installed that did not require human physical effort to operate. All of these systems helped supply water to meet Nineveh's enormous needs throughout the year; but in spring, with the melting mountain snow, floods formed that could cause damage. To address this problem, Sennacherib designed an excess water discharge system that directed unnecessary water outside the city to specially designed artificial ponds. It is one of the oldest known and the first-described sewage pond regulating excess water, based on the principles of sustainable architecture, which is especially relevant in our time. ${ }^{62}$ The design of these ponds was inspired and developed after Sennacherib's successful military expedition to the then semi-independent, rebel province of Assyria, Babylon, which ended in the destruction of the latter city. Therefore, this nature reserve was planted with plants and animals and birds typical of southern Mesopotamia, which is much wetter, and therefore likely to be poorly adapted, ${ }^{63}$ thus symbolically emphasizing not only nature but also the kingdom of Babylon. The natural area of this artificial pond, which was near the city gate of Kar-Mulissi (Figure 9), allowed wildlife to breed and reproduce naturally. Over time, this area, having reached the stage of maturity, became dangerous for local people coming to enjoy the reed harvest that was abundant here.

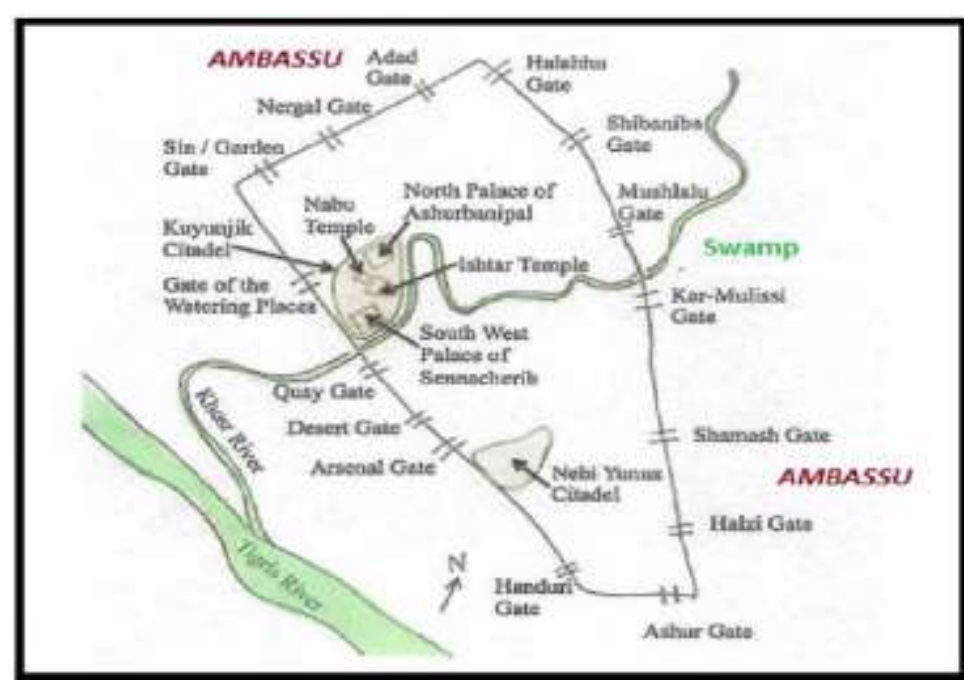

Figure 9. Urban Structure of the City and Surroundings of Nineveh Source: Patrick, 2016.

62. Mays, Ancient Water Technologies, 2010, 7, 38.

63. Dalley "Ancient Mesopotamian Gardens and the Identification of the Hanging Gardens of Babylon," 1993. 
The most important gardens, from Sennacherib's perspective, were his own royal gardens, located within the city walls of the Kuyunjik Citadel. They were nodoubt perfectly planned and decorated, and every element had to be thought through in detail, as these were the most important gardens of the empire. They were meant for the pleasure and joy of the gods and the king and his queen, as well as for ritual rites. These royal gardens were laid out in such a way as to provide easy access to temples and royal residences. ${ }^{64}$ In addition, based on the latest hypotheses and research, Sennacherib is credited with realizing one of the wonders of the ancient world, the Hanging Gardens. Typically, these gardens, based on Greek sources, were attributed to Babylon, but until recently there were no archeological or Babylonian textual sources to determine the location and characteristics of the hanging Babylonian gardens, which allowed many speculations to occur. However, S. Dalley argues, using reasoned arguments, that Greek sources relied on gardens built by King Sennacherib of Assyria, Nineveh. They, in her opinion, are also depicted in the reliefs of Nineveh (Figure 10). Nineveh and Babylon were often confused by biblical, classical, and authors of later times, and thus Sennacherib of Assyria was merged with Nebuchadnezzar II of Babylon. The gardens, according to S. Dalley, were built on an artificial hill next to the palace and were designed and laid out to mimic a natural mountainous landscape with trees and flowing water. The shape and dimensions were similar to Greek theater (Figure 11), and the water was supplied to the top by bronze screws mounted in cylinders. The present invention is often attributed to Archimedes several centuries later, but images of propellers are found in Assyrian reliefs. Sennacherib's annals also testify to this garden. He is proud of the new water supply technologies that have earned them the name of a world wonder. ${ }^{65}$ The stone vaults supported the upper part of the gardens; the highest levels consisted of open terraces and columned paths with roofs planted with trees so that visitors walked under the roots, and the gardens were equipped with a pavilion with columns, bitumen, and probably in the lowest level was a recreational lake. ${ }^{66}$

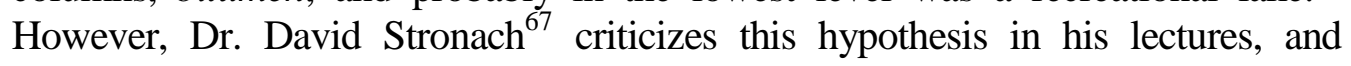
although he agrees with the possible argumentation of confusion between Nineveh and Babylon in classical sources, he believes that such gardens near the royal palace, especially the artificial lake, are unlikely as they block and impede the most obvious and direct access to the palace. The relief, he argues, depicting the gardens of Nineveh is of a more abstract nature, conveying not so much a realistic world, rather a picture with all the achievements of the ruler in one place.

64. Patrick, The Imperial Gardens of Mesopotamia: Landscapes of Power, 2016, 35-38.

65. Dalley "Ancient Mesopotamian Gardens and the Identification of the Hanging Gardens of Babylon," 1993, 7-10.

66. Taylor (Ed.), The Oxford Companion to the Garden, 2006.

67. D. Stronach, Ancient Persian Gardens: Evolution and Legacy (video) Retrieved from: https://www.youtube.com/watch? $\mathrm{v}=43 \mathrm{kX}$ QWHy6M\&ab channel=AsianArtMuseum. [Accessed 30 March 2021.] 


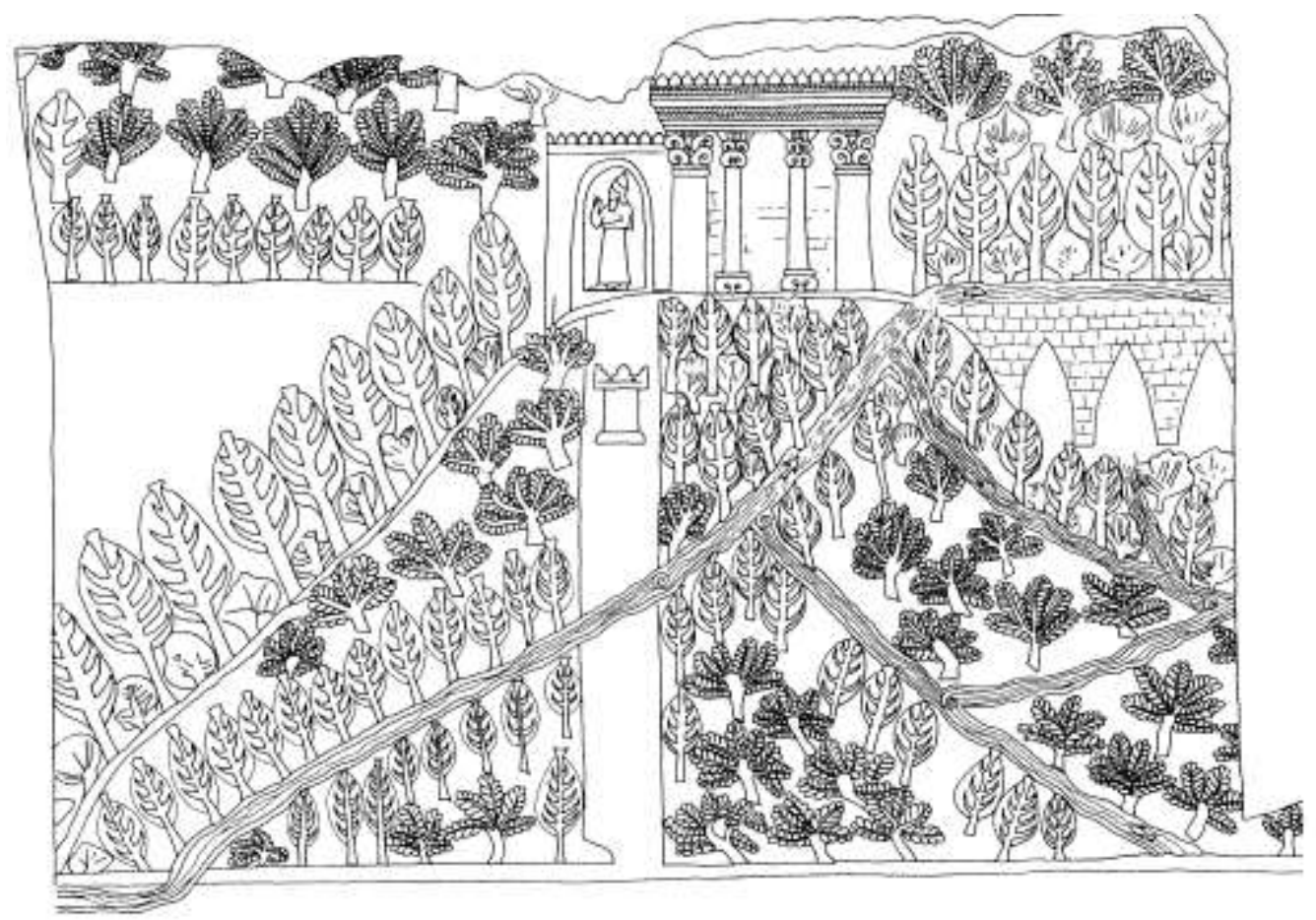

Figure 10. Nineveh Gardens, Believed to Possibly Convey "Hanging Gardens," Repainted by $S$. Dalley from a Fragment of Relief Source: Dalley, 1993, 10.

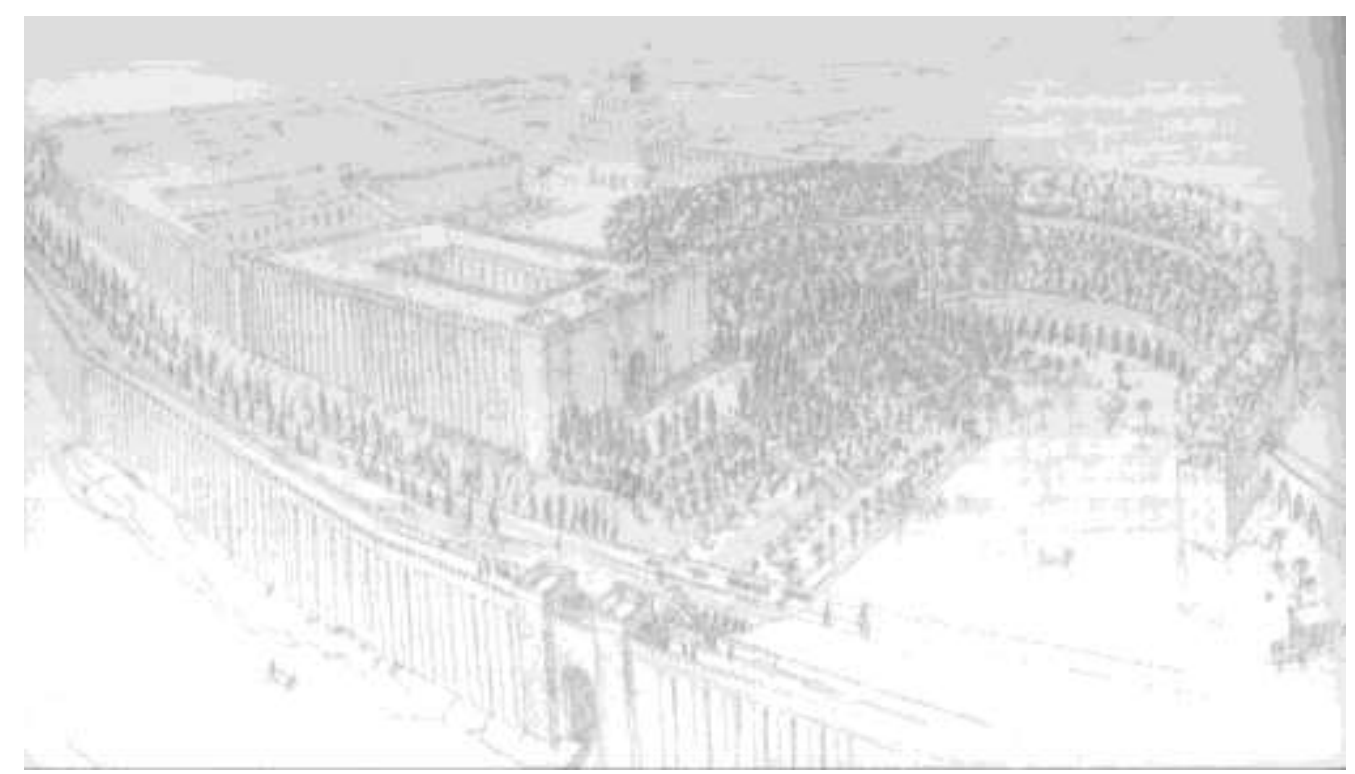

Figure 11. Visualization of Hanging Gardens in Nineveh Source: Taylor, 2006, 30. 


\section{Iconography of Mesopotamian Gardens}

In the context of Assyria, all gardens and parks were permeated with sacral meaning. The gardens were the meeting place of the gods, and also mediated between man and the gods. They were imbued with religious, cult, magical and political underpinnings. The visual discourses of the ritual rites taking place in them became forms of political-religious indoctrination. Textual sources indicate that the gods of both Babylon and Assyria also had personal, private gardens in their heavenly habitats. ${ }^{68}$ However, in addition to the physical manifestation, the Assyrian gardens also had a visual representation conveyed in the reliefs of the royal palace. A particularly large number of such reliefs are found in the new palace built by Ashur-nasir-pal II, the grandson of Sennacherib, who continued to nurture his grandfather's gardens in Nineveh. Such a relief, called The Garden Party (Figure 12), depicts a resting king with a queen in the gardens of Nineveh after the victory over Elam, where the head of King Teumman's is evidently hung on a tree. In the hands of the ruler is a water lily; it is believed that these gardens had one or more ponds, the latter being covered with their flowers. Scientists believe that water lilies (Nymphaea) in Mesopotamia originated from Egypt. ${ }^{69}$ The image of these depicted royal gardens conveys a complex composition based on a high level of layout and design, combining different greenery. Art historian P. Albenda reconstructed the full context of the image of this relief (Figure 13), revealing that the image was found in three registers depicting a wider panorama. The upper register, which contains the original relief, is dedicated to the king and depicts the gardens closest to the palace. The middle register depicts more public hunting gardens, and the last, lower register, conveys artificial ponds outside the city walls. This layout reveals that the gardens closest to the royal palace were most carefully designed for ritual activities, but the gardens farther away from the palace deliberately used far less formality by compositional means, even in forms of permissible chaos, and uncontrolled nature. ${ }^{70}$ After a more detailed analysis of Assyrian gardens, A. Asadpor also drew conclusions about the existing connection between the center and the periphery, and the level of application of geometric planning and design. In the center, the gardens of the palaces or temples of the rulers apply the highest degree of design, which decreases steadily as you move towards the peripheries. Such planning is related to the dichotomy of order/chaos, conveying the ideological worldview of Assyria. In this context, the city is to be treated as a symbol of order, and wildlife as an opposition to unrest and chaos. The king, as a trustee of God, introduces order and harmony in a chaotic world, which is especially noticeable as he approaches from the periphery to the center. As a result, fully-fledged gardens flourished throughout the Assyrian Empire, the culmination and apogee of which were entrenched in the imperial capital, thus

68. Patrick, The Imperial Gardens of Mesopotamia: Landscapes of Power, 2016, 39.

69. Albenda, “Grapevines in Ashurbanipal's Garden," 1974, 6.

70. Amrhein, "Neo-Assyrian Gardens: A Spectrum of Artificiality, Sacrality and Accessibility," 2015, 100. 
emphasizing the political, ideological, and religious dominance of the Assyrians in the country. ${ }^{71}$

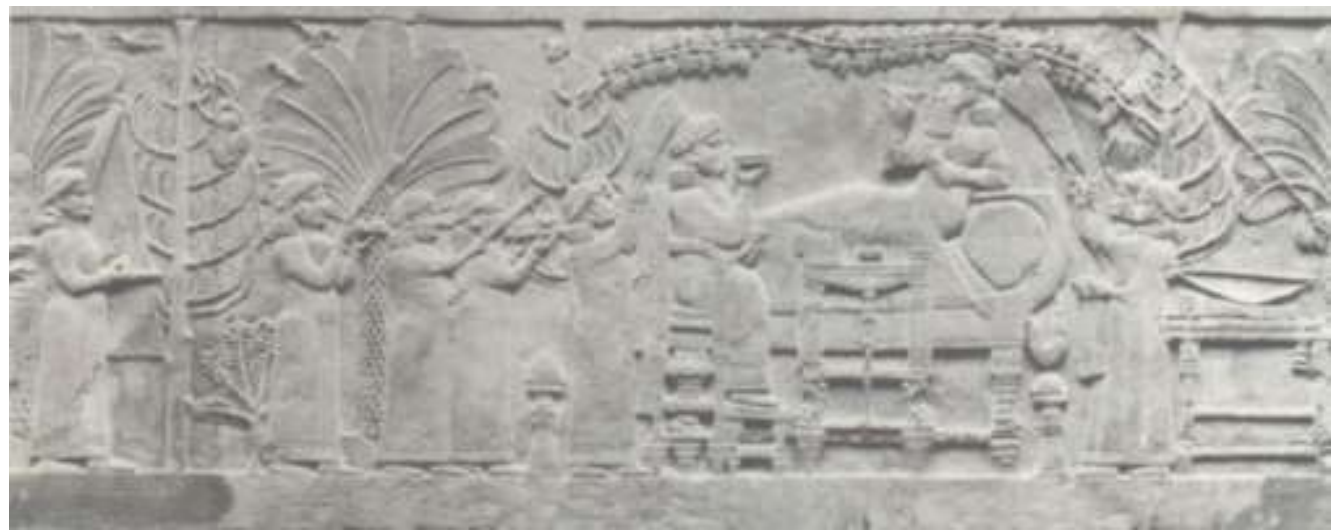

Figure 12. Asurbanipal II Palace "Garden Party" Terrain

Source: Rogers, 2001, 39.

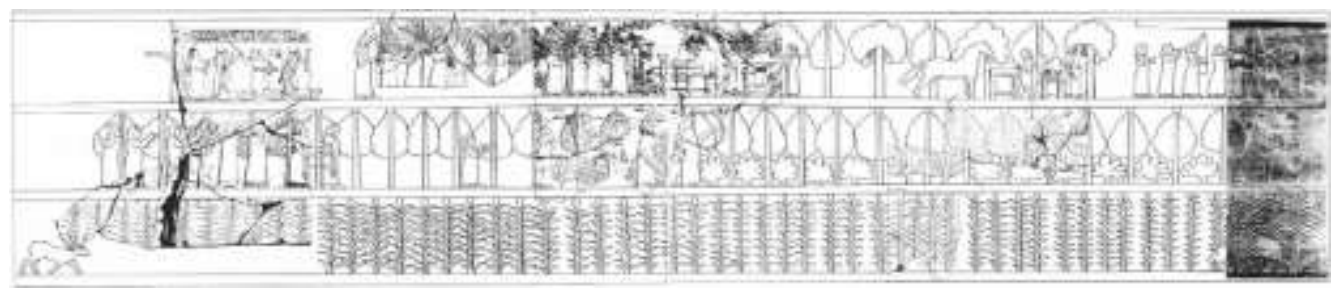

Figure 13. Reconstructed Full-Length Reconstruction of "Garden Party" by P. Albenda

Source: Amrhein, 2015, 100.

The Iconography of the gardens themselves, as well as their visual representation, played an equally important ideological role in propaganda. In the conceptual perception of the world in Mesopotamia, both Babylon and Assyria, the visual did not differ from the real world, and was a more active factor than just the visual representation of the environment. A phenomenon, object, or person could have been easily reached through its visual representation or even in name. Those who had access to the reliefs perceived them in a context adjacent to the physical gardens, and therefore gained a fuller experience, and a broader perception of the reliefs. However, real gardens have more sensory features such as smell, sound, and space, creating a deeper mental spectacle, and the perception of terrain requires some education, iconography, and symbolism, making it a more conceptual experience as opposed to direct physical garden experiences. In this way, the "sixth sense" is used to understand the reliefs, which requires specialized doctrinal knowledge. ${ }^{72}$ Thus, gardens were magical places where sculptures of gods were perceived as equally real and could be revived during ritual rites. ${ }^{73}$

71. Asadpor, "Phenomenology of Garden in Assyrian Documents and Reliefs; Concepts and Types," 2018

72. Amrhein, "Neo-Assyrian Gardens: A Spectrum of Artificiality, Sacrality and Accessibility," 2015, 107-108.

73. Patrick, The Imperial Gardens of Mesopotamia: Landscapes of Power, 2016, 66. 
Looking more broadly, it is clear that textual rhetoric was aimed at the educated elite, future generations and most importantly, the gods. Visual iconography in relief was for those who lived or worked in the palace, foreign kings or diplomats, and gardens more symbolic than real physical places for the general public. Thus, the conceptual discourse of gardens was widely developed on many levels and functioned inextricably as a message of propaganda, indoctrination, cult, and ideology. For greater persuasiveness, gardens have been eroticized in both religious and poetic texts, providing a wide variety of allegories. In order to achieve the mystery effect, the rituals of the gods were also performed here in the second month of the Assyrian calendar, during which the cult statue of Nabu was transferred to the cult statue's Tashmetum bedroom. ${ }^{74}$ Thus, the image was established that fertility, fruitfulness, and the prosperity of the kingdom were given to the people by the gods, and were supported and cherished by the kings of Assyria. The reliefs established the image of Assyria as the center of civilization, from which the order spread to the otherwise chaotic peripheries. The gardens were designed to convey the king's control over the environment — land, water and plants - thus strengthening his authority. The greenery brought from the conquered lands was treated not only as trophies, but also symbolized dominance over the conquered nations.

\section{Conclusions}

The technology of Mesopotamian gardens originated in the early period of the Eridu and the influence of this garden art spread over time to Egypt, Susa in Media, Mohenjo-Daro in the Indus Valley and Pataliputra in the Mauryan Empire of India. In Europe, this influence was first manifested in the construction of the Minoan palaces in Crete. ${ }^{75}$ In Mesopotamia, two different types of gardens are traditionally distinguished; the Assyrians are characterized by northern-type gardens, most of which are more free in layout and tend to mimic the natural landscape, and southern-style gardens, typical of the Sumerians and Babylonians, with geometric planning structures, are mostly associated with temples and cult needs. However, courtyard gardens found in palaces can also be singled out in this region. ${ }^{76}$ The famous Hanging Gardens of Babylon, while not reaching the visual form of our time, have been heating our imaginations for centuries and causing different interpretations at different times, which in turn deserve special attention in the evolution of the idea of landscape architecture.

Clearly, gardens in ancient Mesopotamia acquired much broader cultural value and served as an agent of cult, worldview doctrine, formalization and dissemination of mythical thinking. Gardening was not only a matter of prestige but also a tool of politics. Some scholars tend to hold the view that the gardens depicted in the Assyrian reliefs are of a clear naturalistic nature and therefore

74. Patrick, The Imperial Gardens of Mesopotamia: Landscapes of Power, 2016, 40.

75. Girot, The Course of Landscape Architecture, 2016, 55.

76. Taylor (Ed.), The Oxford Companion to the Garden, 2006, 308-309. 
cannot be the origins of geometric Persian gardens. ${ }^{77}$ However, to declare it in this way would be too narrow approach.

Many scholars point out that although Assyrian gardens are more naturalistic than geometric, ornamental Egyptian gardens or Mediterranean peristyle gardens, they do not have a sentimental and romantic attachment to nature as did the 18thcentury English or three-thousand-year-old Chinese, and later Korean and Japanese gardens. ${ }^{78}$ Therefore, in comparison, it is not appropriate to look at them as more natural or wild, but equivalent, or even more artificial and decorative, as they primarily sought to imitate alien landscapes. ${ }^{79}$ Nonetheless, as the authoritative scholar D. Stronach observes, for the first time in the history of Mesopotamia the tradition of royal, public gardens developed, and this culture of gardens as a political tool was first adopted by the Persians and later by other surrounding civilizations. ${ }^{80}$ It is clear that ancient Mesopotamia occupies a fundamental place in the development of world garden art.

\section{Bibliography}

Albenda, P. "Grapevines in Ashurbanipal's Garden." Bulletin of the American Schools of Oriental Research no. 215 (1974).

Amrhein, A. "Neo-Assyrian Gardens: A Spectrum of Artificiality, Sacrality and Accessibility." In Studies in the History of Gardens \& Designed Landscapes, 91-114. 2015.

Andrijauskas, A. Civilizacijos istorijos metamorfozès: komparatyvistinis požiūris $i$ neeuropini pasauli. (Metamorphoses in the History of Civilization: A Comparative Analysis of the Non-European World.) Vilnius: LKTI, 2018. . Rytu Azijos tradicine estetika ir meno teorija. (Far East Traditional Aesthetics and Art Theory.) Vilnius: LKTI, 2017.

Asadpor, A. "Phenomenology of Garden in Assyrian Documents and Reliefs; Concepts and types." Bagh-e Nazar 15, no. 60 (2018): 55-66.

Britannica. Retrieved from: https://www.britannica.com/art/fountain/. [Accessed 30 March 2021.]

Campbell C. S. Water in Landscape Architecture. New York: Van Nostrand Reinhold Company, 1978.

Charpin D. "The History of Ancient Mesopotamia: An Overview." In Civilizations of the Ancient Near East, edited by J. Sasson et al., 807-829. New York, 1995.

Dalley S. "Ancient Mesopotamian Gardens and the Identification of the Hanging Gardens of Babylon" Garden History 21, no. 1 (1993).

Davies P. J. E., W. B. Denny, F. F. Hofrichter, J. F. Jacobs, A. S. Roberts, et. al. Janson's History of Art: The Western Tradition. 8th Edition. London: Laurence King Publishing Ltd, 2010.

77. Dalley "Ancient Mesopotamian Gardens and the Identification of the Hanging Gardens of Babylon," 1993.

78. P. Grecevičius, J. Abromas, et. al., "Aspects of Continuity of Historic Japanese Traditions in Lithuanian Landscape Design," in Proceedings of the 52th World Congress of the International Federation of Landscape Architecture "History of the Future" (Saint-Petersburg, 2015), 519-526.

79. Amrhein, "Neo-Assyrian Gardens: A Spectrum of Artificiality, Sacrality and Accessibility," 2015, 91-114.

80. Stronach, "The Garden as a Political Statement: Some Case Studies from the Near East in the First Millennium BC," Bulletin of the Asia Institute, New Series 4 (1990): 171-180. 
Girot, C. The Course of Landscape Architecture. Thames \& Hudson, 2016.

Grecevičius, P., J. Abromas et al. "Aspects of Continuity of Historic Japanese Traditions in Lithuanian Landscape Design." In Proceedings of the 52th World Congress of the International Federation of Landscape Architecture "History of the Future". Saint Petersburg, 2015: 519-526.

Jamieson, A. "Empires of Ancient Mesopotamia." Agora 51, no. 3 (2016): 45-51.

Jellicoe, G. A. and S. Jellicoe. The Landscape of Man: Shaping the Environment from Prehistory to the Present Day. Thames and Hudson, 1995.

Kramer S. N. The Sumerians: Their History, Culture and Character. Chicago: The University of Chicago Press, 1963.

Laurie, M. An Introduction to Landscape Architecture. Elsevier, 1986.

Luckenbill, D. D. The Annals of Sennacherib. Chicago: The University of Chicago Oriental Institute Publications, 1924.

Mark J. J. Babylon. 2011. Retrieved from: https://www.ancient.eu/babylon/. [Accessed 30 March 2021.]

Mays, L. W. Ancient Water Technologies. Dordrecht, Heidelberg, London, New York: Springer, 2010.

Novak, M. "From Ashur to Nineveh: The Assyrian Town-Planning Programme." In Papers of XLIXe Rencontre Assyriologique Internationale 1 (Iraq 66), London, 2004.

Patrick, D. P. The Imperial Gardens of Mesopotamia: Landscapes of Power, 2016. Retrieved from: https://bit.ly/3iG8laA. [Accessed 30 March 2021.]

Plumptre, G. The Water Garden - Styles, Designs and Visions. Thames \& Hudson Ltd., 1993.

Pournelle, J. R. "KLM to CORONA: A Bird's Eye View of Cultural Ecology and Early Mesopotamian Urbanization." In Settlement and Society: Essays Dedicated to Robert McCormick Adams, edited by Elizabeth C. Stone. Cotsen Institute of Archaeology, UCLA and Oriental Institute of the University of Chicago, 2007.

Rogers, E. R. Landscape Design: A Cultural and Architectural History. Abrams, 2001.

Stiebing W. H. Jr. and S. N. Helft. Ancient Near Eastern History and Culture. Routledge, 2017.

Stronach, D. "The Garden as a Political Statement: Some Case Studies from the Near East in the First Millennium BC." Bulletin of the Asia Institute, New Series 4 (1990): 171180.

. Ancient Persian Gardens: Evolution and Legacy (video) Retrieved from: https:// www.youtube.com/watch?v=43kX_QWHy6M\&ab_channel=AsianArtMuseum with Dr. David Stronach [Accessed 30 March 2021.]

Taylor, P. (Ed.) The Oxford Companion to the Garden. Oxford University Press, 2006.

The Gardens of Babylon. Retrieved from: https://www.wonders-of-the-world.net/Seven/ Gardens-of-Babylon.php/. [Accessed 30 March 2021.]

Wiseman, D. J. “Mesopotamian Gardens.” Anatolian Studies 33 (1983): 137-144. 
